\title{
PENGHINDARAN PAJAK PADA PERUSAHAAN MANUFAKTUR SEKTOR PERTAMBANGAN DAN PERTANIAN TAHUN 2015-2018
}

\author{
Dewi Manuturi ${ }^{1 *}$, Dian Hakip Nurdiansyah ${ }^{2}$ \\ ${ }^{1,2}$ Universitas Singaperbangsa Karawang \\ dian.hakipnurdiansyah@staff.unsika.ac.id
}

\begin{abstract}
ABSTRAK
Penelitian ini bertujuan untuk mengetahui apakah terdapat pengaruh Ukuran Perusahaan, Sales Growth dan Profitabilitas terhadap Penghindaran Pajak secara parsial maupun bersama-sama. Metode yang digunakan dalam penelitian ini adalah metode deskriptif verikatif dengan pendekatan kuantitaf yang bersumber dari laporan keuangan perusahaan sektor pertambangan dan pertanian serta studi pustaka. Teknik pengambilan sampel menggunakan non probability sampling dengan teknik sampling purposive. Data yang diperoleh dianalisis dengan pengujian keabsahan data, analisis regresi linier berganda dan uji hipotesis menggunakan uji t dan uji f. Penelitian ini menggunakan program SPSS versi 25 untuk mengolah data. Hasil penelitian ini menunjukkan bahwa, Ukuran Perusahaan tidak berpengaruh terhadap Penghindaran Pajak, Sales Growth tidak berpengaruh terhadap Penghindaran Pajak, Profitabilitas tidak berpengaruh terhadap Penghindaran Pajak.
\end{abstract}

Kata Kunci : Ukuran Perusahaan, Sales Growth, Profitabilitas dan Penghindaran Pajak.

\section{PENDAHULUAN}

Indonesia merupakan negara yang berkembang yang memiliki berbagai macam potensi untuk menjadi negara yang lebih maju. Bagi negara-negara yang ada di dunia ini pajak merupakan unsur penting dan bahkan paling penting dalam rangka untuk menopang anggaran penerimaan negara. Oleh karenanya pemerintah negara-negara di dunia ini begitu besar menaruh perhatian terhadap sektor pajak. Namun hingga saat ini permasalahan pajak di Indonesia tidak henti-hentinya muncul, padahal pajak merupakan suatu kewajiban masyarakat sebagai warga negara tetapi masih banyak saja masyarakat yang enggan membayar pajak. Yang dimana hal tersebut dapat menyebabkan kerugian bagi negara. Fenomena penghindaran pajak di Indonesia dapat dilihat dari rasio pajak negara Indonesia (Handayani, 2018; Handayani, 2018).

Indonesia telah bersepakat untuk menerapkan the Automatic Exchange of Information (AEOI) dalam rangka mengurangi upaya-upaya penghindaran pajak tersebut. Pemerintah Indonesia antara lain telah menerbitkan Peraturan Pemerintah Pengganti UU (Perppu) No. 1 Tahun 2017 tentang Akses Informasi Keuangan Untuk Kepentingan Perpajakan. Berbeda dengan negara dimana pajak merupakan sumber penerimaan, bagi perusahaan pajak merupakan hal yang dianggap tidak menguntungkan, karena pajak merupakan beban yang akan berdampak pada berkurangnya laba yang dihasilkan perusahaan (Anouar dan Houria, 2017; Dewinta dan Setiawan, 2016). Penggelapan pajak (tax evasion) diartikan sebagai kegiatan ilegal dalam usaha pengurangan pembayaran pajak (Razali, Brahmana \& Tak, 2019; Prastiwi dan Ratnasari, 2019). Perusahaan akan lebih memilih melakukan usaha pengurangan pajak melalui penghindaran pajak karena usaha pengurangan pajak yang dilakukan tetap mematuhi ketentuan peraturan perpajakan seperti memanfaatkan pengecualian dan potongan yang diperkenankan maupun menunda pajak yang belum diatur dalam peraturan perpajakan yang berlaku (Pattasina et al. 2019). Mardiasmo (2016:10) mengungkapkan bahwa hambatan-hambatan yang dihadapi oleh Ditjen Pajak dalam 
melakukan pemungutan pajak disebabkan karena adanya perlawanan dari Wajib pajak. Tax evasion merupakan usaha menurunkan beban pajak dengan melanggar undang-undang yakni menggelapkan pajak (Razali, Brahmana dan Tak, 2019). Ukuran perusahaan adalah besar kecilnya perusahaan dapat diukur dengan total aktiva atau besar harta perusahaan dengan menggunakan perhitungan logaritma total aktiva (Hartono, 2015). Semakin besar ukuran perusahaannya, maka perusahaan akan lebih mempertimbangkan risiko dalam hal mengelola beban pajaknya (Handayani, 2018). Jadi hal itu memungkinkan perusahaan untuk memanfaatkan celah-celah yang ada untuk melakukan tindakan tax avoidance dari setiap transaksi. Laba yang besar dan stabil yang dimiliki perusahaan berukuran besar cenderung mendorong perusahaan untuk melakukan kegiatan penghindaran pajak dalam perusahaan (Turyatini, 2017). Hal tersebut sesuai dengan peneliti yang dilakukan oleh Swingly dan Sukartha (2015) dan Okrayanti, Utomo dan Nuraina (2017) serta Putri dan Suryarini (2017) yang menyatakan bahwa ukuran perusahaan berpengaruh positif pada penghindaran pajak. Berbeda dengan penelitian yang dilakukan oleh Mahanani,Hendra dan Nurlela (2017) dan Permata, Nurlela dan Wahyuningsih (2018) serta Kimsen, Kismanah dan Masitoh (2018) yang menyatakan bahwa ukuran perusahaan tidak berpengaruh pada tax avoidance, perusahaan besar akan mendapat perhatian yang lebih besar dari pemerintah terkait dengan laba yang diperoleh. Profitabilitas digunakan untuk mengukur efektivitas manajemen secara keseluruhanyang ditunjukkan oleh besar kecilnya tingkat keuntungan yang diperoleh dalam hubungannya dengan penjualan maupun investasi (Fahmi, 2017; Yanti dan Hartono, 2019; Dewinta dan Setiawan (2016), Irianto, Sudibyo dan Wafirli (2017). Adapun dalam penelitian Puspita dan febrianti (2017; Putri dan Suryarini (2017), Nurlela dan Wahyuningsih (2018) serta Hidayat (2018) menunjukkan bahwa ROA tidak berpengaruh terhadap tax avoidance.
Penelitian ini menggunakan pengukuran pertumbuhan penjualan karena dapat menggambarkan baik atau buruknya tingkat pertumbuhan penjualan suatu perusahaan sehingga perusahaan dapat memprediksi seberapa besar profit yang akan diperoleh dengan besarnya pertumbuhan penjualan (Pranata dan Pujiati, 2015). Peningkatan pertumbuhan penjualan cenderung akan membuat perusahaan mendapatkan profit yang besar. Berbeda dengan Swingly dan Sukartha (2015) dan Hidayat (2018) yang menyatakan bahwa sales growth tidak berpengaruh signifikan terhadap tax avoidance.

\section{KAJIAN PUSTAKA PENGEMBANGAN HIPOTESIS Akuntansi Perpajakan}

Menurut Sukrisno Agoes dan Estralita Trisnawati (2017:10), Waluyo ( 2016:35) akuntansi pajak adalah pencatatan transaksi yang berhubungan dengan pajak untuk mempermudah penyusunan Surat Pemberitahuan Pajak (SPT) masa dan tahunan pajak penghasilan. Menurut Mardiasmo (2016:8) sistem pemungutan pajak dibagi atas 3 (tiga) macam yaitu, Official Assesment System, Self Assessment System dan With Holding System. Menurut Pohan 2015:3 manajemen pajak adalah sarana untuk memenuhi kewajiban perpajakan dengan benar tetapi jumlah pajak yang dibayar dapat ditekan serendah mungkin untuk memperoleh laba dan likuiditas yang diharapkan. Manajemen pajak merupakan upaya dalam melakukan penghematan pajak secara legal.

\section{Manfaat Manajemen Pajak}

Menurut Prastiwi dan Ratnasari, 2019; Hidayat 2018; Puspita dan Febrianti 2017; Firmansyah dan Muliana(2018); Turyatini (2017) penghindaran pajak adalah upaya yang dilakukan untuk meminimalkan kewajiban pajak secara legal dan aman bagi wajib pajak karena tidak bertentangan dengan ketentuan perpajakan atau masih dalam koridor hukum. 


\section{Sales Growth (Pertumbuhan Penjualan)}

Kasmir (2017:107) ; Mappanyuki dan Sari 2017; Pranata dan Pujiati, 2015). Perusahaan dapat mengoptimalkan dengan baik sumber daya yang ada dengan melihat penjualan dari tahun sebelumnya. Pengukuran pertumbuhan penjualan dapat menggambarkan baik atau buruknya tingkat pertumbuhan penjualan suatu perusahaan. Perusahaan dapat memprediksi seberapa besar laba yang akann diperoleh dengan melihat besarnya pertumbuhan penjualan. Dewinta dan Setiawan (2016) mengatakan bahwa peningkatan pertumbuhan penjualan cenderung akan membuat perusahaan mendapatkan laba yang besar, maka dari itu perusahaan akan cenderung untuk melakukan praktik tax avoidance.

\section{Profitabilitas}

Fahmi (2017:81); Hery (2016:192); Kasmir (2017:196) rasio profitabilitas adalah rasio untuk mengukur seberapa besar sebuah perusahaan mampu menghasilkan laba dengan menggunakan semua faktor perusahaan yang ada didalamnya untuk menghasilkan laba yang maksimal. Semakin tinggi nilai profitabilitas berarti semakin baik kinerja perusahaan dalam menggunakan aset tersebut sehingga keuntungan besar diperoleh perusahaan (Kimsen, Kismanah, dan Masitoh, 2018).

\section{METODOLOGI PENELITIAN Populasi dan Sampel}

Dalam penelitian ini penulis menggunakan metode penelitian kuantitatif dengan pendekatan deskriptif dan verikatif, karena untuk menyajikan gambaran mengenai variabel- variabel yang diteliti serta untuk menunjukkan hubungan antara variabelvariabel yang diteliti. Populasi pada penelitian ini adalah perusahaan manufaktur sektor pertambangan dan pertanian yang terdaftar pada Bursa Efek Indonesia pada periode 2015-2018 yakni sebanyak 61 perusahaan. Dengan Sampel pada penelitian ini terdiri dari 9 perusahaan Teknik sampling merupakan teknik pengambilan sampel (Sugiyono, 2017:139). Teknik sampling yang digunakan dalam penelitian ini adalah purposive sampling. Penarikan sampel purposive adalah penarikan sampel dengan pertimbangan tertentu (Suharyadi dan Purwanto, 2015:17). Dalam penelitian ini, peneliti menggunakan data sekunder maka sebelum melakukan analisis regresi perlu dilakukan uji asumsi klasik untuk menghindari timbulnya penyimpangan. Uji asumsi klasik terdiri dari beberapa pengujian yaitu uji normalitas, setelah dilakukan hasil pengujian yaitu nilai signifikasi pada Asymp Sig. (2-tailed) sebesar 0,200 dan lebih besar dibandingkan dengan 0,05. Hal ini menunjukkan asumsi normalitas terpenuhi atas data residual berdistribusi normal. Selajutnya, uji autokorelasi, Berdasarkan hasil uji autokorelasi maka dapat diperoleh nilai DurbinWatson yaitu sebesar 1,700 artinya nilai Durbin- Watson dalam penelitian ini masih berada diantara -2 sampai dengan +2 . Oleh karena itu dapat disimpulkan bahwa analisis regresi linier berganda dalam penelitian ini bebas dari uji autokorelasi. Lalu, uji heteroskedastisitas, bahwa titik-titik tidak membentuk pola dan uji multikolinieritas, menunjkkan nilai tolerance ukuran perusahaan, sales growth dan profitabilitas yang memiliki nilai $>0,1$ dan nilai VIF $>10$. Dengan demikian dapat disimpulkan bahwa tidak terjadi masalah multikolonieritas dalam penelitian ini.

\section{Metode Analisis Data}

Analisis ini digunakan untuk mengukur besarnya pengaruh ukuran perusahaan, sales growth, dan profitabilitas terhadap penghindaran pajak. Persamaan analisis regresi linear secara umum untuk menguji hipotesishipotesis dalam penelitian ini dirumuskan sebagai berikut: Rumus:

$$
Y=\alpha+\beta 1 X 1+\beta 2 X 2+\beta 3 X 3+e
$$




\section{HASIL DAN PEMBAHASAN}

Hasil statistik deskriptif atas seluruh variabel dalam penelitian ini adalah seperti terlihat dalam tabel 1

Tabel 1 Uji Statistika Deskriptif

\begin{tabular}{|c|c|c|c|c|c|c|c|c|}
\hline & \multirow{2}{*}{$\begin{array}{c}\mathrm{N} \\
\text { Statistic }\end{array}$} & \multirow{2}{*}{$\begin{array}{r}\text { Range } \\
\text { Statistic } \\
\end{array}$} & \multirow{2}{*}{$\begin{array}{r}\text { Minimum } \\
\text { Statistic } \\
\end{array}$} & \multirow{2}{*}{$\begin{array}{r}\text { Maximum } \\
\text { Statistic } \\
\end{array}$} & \multirow{2}{*}{$\begin{array}{c}\text { Sum } \\
\text { Statistic }\end{array}$} & \multicolumn{2}{|c|}{ Mean } & \multirow{2}{*}{$\begin{array}{l}\text { Std. Deviation } \\
\text { Statistic }\end{array}$} \\
\hline & & & & & & Statistic & Std. Error & \\
\hline Ukuran_Perusahaan & 36 & 13,14 & 14,58 & 27,72 & 669,38 & 18,5940 &, 80586 & 4,83517 \\
\hline Sales_Growth & 36 & ,97 &, 02 & ,99 & 19,33 &, 5369 &, 06286 &, 37717 \\
\hline Profitabilitas & 36 & ,24 &, 00 &, 24 & 2,60 & 0722 & ,00928 & 05567 \\
\hline Penghindaran_Pajak & 36 &, 84 & ,14 & ,98 & 13,12 & 3644 & 02999 & ,17997 \\
\hline Valid N (listwise) & 36 & & & & & & & \\
\hline
\end{tabular}

Sumber : Data diolah, 2020

Berdasarkan hasil pengujian pada tabel 1 hasil analisis deskriptif atas variabel penghindaran pajak (CETR) pada perusahaan manufaktur sektor pertambangan dan pertanian yang terdaftar di BEI tahun 2015-2018 rata-rata sebesar menunjukkan nilai minimum penghindaran pajak sebesar 0,14 adalah PT. Tunas Baru Lampung Tbk pada tahun 2016, sedangkan nilai maksimum sebesar 0,98 adalah PT. Astra Argo Lestari Tbk pada tahun 2015, rata-rata perusahaan yang diteliti dalam penelitian ini yang melakukan penghindaran pajak sebesar 0,3644, dan nilai standar deviasi sebesar 0,17997. Hasil pengujian statistik deskriptif pada variabel ukuran perusahaan (size) menunjukkan nilai minimum ukuran perusahaan sebesar 14,58 adalah PT. BISI Internationa Tbk pada tahun 2015, sedangkan nilai maksimum sebesar 27,72 adalah PT. Radiant Utama Interinsco Tbk pada tahun 2015, rata-rata ukuran perusahaan yang diteliti sebesar 18,5940, dan nilai standar deviasi sebesar 4,83517 .

Tabel 2 Rangkuman Hasil Analisis linier berganda

\begin{tabular}{|l|c|c|c|}
\hline \multicolumn{1}{|c|}{ Hipotesis } & $\begin{array}{c}\text { Nilai (t- } \\
\text { statistik) }\end{array}$ & Sign. & Ket \\
\hline Constant & 2.017 & 0.052 & - \\
\hline $\begin{array}{l}\text { Ukuran_Perusahaan } \\
\text { (H1) }\end{array}$ & 0.300 & 0.766 & Ditolak \\
\hline
\end{tabular}

\begin{tabular}{|l|c|c|c|}
\hline Sales_Growth (H2) & 0.926 & 0.361 & Ditolak \\
\hline $\begin{array}{l}\text { Profitabilitas (H3) } \\
\text { Adjusted R- } \\
\text { squared }\end{array}$ & -1.725 & 0.094 & Ditolak \\
\hline $\begin{array}{l}\text { Prob F } \\
\text { Statistik }\end{array}$ & \multicolumn{3}{|c|}{0,132} \\
\hline
\end{tabular}

Sumber: Data diolah SPSS 22, 2020

\section{Pengaruh Ukuran Perusahaan Terhadap Penghindaran Pajak}

Berdasarkan hasil penelitian pengujian dengan demikian, didapat kesimpulan bahwa tidak adanya pengaruh ukuran perusahaan terhadap penghindaran pajak. Dan memiliki nilai konstanta sebesar 0,002 yang berarti apabila terjadi peningkatan pada ukuran perusahaan maka akan diikuti oleh kenaikan penghindaran pajak dan demikian pula sebaliknya. Rata-rata ukuran perusahaan pada perusahaan sektor pertambangan dan pertanian periode 2015-2018 yang diteliti sebesar 18,5940. Dengan demikian, didapat kesimpulan bahwa tidak terdapat pengaruh yang signifikan antara ukuran perusahaan terhadap penghindaran pajak. Hal ini mengindikasi bahwa peningkatan ukuran perusahaan atau penurunan ukuran perusahaan selama periode penelitian tidak mempengaruhi penghindaran pajak secara signifikan. Hal ini sesuai dengan hasil penelitian Mahanani, Hendra \& Nurlela (2017) dan Kimsen , Kismanah dan Masitoh 
(2018) yang menyatakan bahwa ukuran perusahaan tidak berpengaruh terhadap penghindaran pajak.

\section{Pengaruh Sales Growth Terhadap Penghindaran Pajak}

Dengan demikian, didapat kesimpulan bahwa tidak adanya pengaruh sales growth terhadap penghindaran pajak. Dan memiliki nilai konstanta sebesar 0,076 yang berarti apabila terjadi peningkatan pada sales growth maka akan diikuti oleh kenaikan penghindaran pajak dan demikian pula sebaliknya. Rata- rata sales growth pada perusahaan sektor pertambangan dan pertanian periode 2015-2018 yang diteliti sebesar 0,5369. Dengan demikian, didapat kesimpulan bahwa tidak terdapat pengaruh yang signifikan antara sales growth terhadap penghindaran pajak. Hal ini mengindikasi bahwa peningkatan sales growth atau penurunan sales growth selama periode penelitian tidak mempengaruhi penghindaran pajak secara signifikan. Hal ini sesuai dengan hasil penelitian yang dilakukan oleh aprianto dan dwimulyani (2019) dan swingly dan sukartha (2016) yang menyatakan bahwa sales growth tidak berpengaruh terhadap penghindaran pajak.

\section{Pengaruh Profitabilitas Terhadap Penghindaran Pajak}

Dengan demikian, didapat kesimpulan bahwa tidak adanya pengaruh profitabilitas terhadap penghindaran pajak. Dan memiliki nilai konstanta sebesar -1,117 yang berarti apabila terjadi peningkatan pada profitabilitas maka akan diikuti oleh kenaikan penghindaran pajak dan demikian pula sebaliknya. Rata- rata profitabilitas pada perusahaan sektor pertambangan dan pertanian periode 2015-2018 yang diteliti sebesar 0,0722. Dengan demikian, didapat kesimpulan bahwa tidak terdapat pengaruh yang signifikan antara profitabilitas terhadap penghindaran pajak.

\section{KESIMPULAN}

Berdasarkan penelitian dan pembahasan yang dilakukan oleh peneliti, maka dapat diambil beberapa kesimpulan, yaitu Pertama, tidak terdapat pengaruh Ukuran Perusahaan terhadap Penghindaran Pajak. yang berarti secara parsial Ukuran Perusahaan tidak berpengaruh terhadap Penghindaran Pajak. Kedua, tidak terdapat pengaruh Sales Growth terhadap Penghindaran Pajak. yang berarti secara parsial Sales Growth tidak berpengaruh terhadap Penghindaran Pajak. Ketiga, tidak terdapat pengaruh Profitabilitas terhadap Penghindaran Pajak. yang berarti secara parsial Profitabilitas tidak berpengaruh terhadap Penghindaran Pajak. Keempat, Tidak terdapat pengaruh Ukuran Perusahaan, Sales Growth dan Profitabilitas terhadap Penghindaran Pajak secara bersama. yang berarti tidak terdapat pengaruh Ukuran Perusahaan, Sales Growth dan profitabilitas terhadap Penghindaran Pajak secara bersama-sama.

\section{DAFTAR PUSTAKA}

Agoes, Sukrisno, dan Trisnawati, Estralita. 2017. Akuntansi Perpajakan. Edisi 3. Jakarta: Salemba Empat.

Bahri, Syaiful. 2016. Pengantar Akuntansi Berdasarkan SAK ETAP Dan IFRS. Yogyakarta: V.Andi.

Fahmi, Irham. 2017. Analisis Laporan Keuangan. Bandung: Alfabeta.

Ghozali, Imam. 2018. Aplikasi Analisis Multivariate dengan Program IBM SPSS 25. Semarang. Badan Penerbit Universitas Diponegoro.

Hanafi, M. Mamduh dan Abdul Halim. 2016. Analisis Laporan Keuangan Yogyakarta: UPP STM YKPN.

Harahap, Mamduh M, dan Halim, Abdul. 2016. Analisis Laporan Keuangan. Edisi Kelima. Yogyakarta:UPP STIM YKPN.

Hartono, Jogiyanto. 2015. Teori Portofolio dan Analisis Investasi Edisi Kesepuluh. Yogyakarta:BPFE.

Hery. 2016. Analisis Laporan Keuangan. Jakarta: Grasindo 
Kasmir, 2017. Analisis Laporan Keuangan. Jakarta: Raja Grafindo Persada Mardiasmo. 2016. Perpajakan. Edisi Revisi. Yogyakarta: Andi.

Martani, Dwi, Siregar, Sylvia Veronica, Wardhani, Ratna, Farahmita, Aria, \& Tanujaya, Edward. 2016. Akuntansi Keuangan Menengah Berbasis PSAK $B u k u$ 1. Edisi 2. Jakarta: Salemba Empat.

Pohan, Chairil Anwar. 2015. Manajemen Perpajakan Strategi Perencanaan Pajak dan Bisnis. Jakarta: Kompas Gramedia.

Resmi, Siti. 2017. Perpajakan Teori dan Kasus. Edisi 10. Jakarta: Salemba Empat.

Soemarso,S.,R. 2017. Akuntansi Suatu Pengantar Buku 1. Edisi 5 Revisi. PT Salemba Empat: Jakarta.

Sugiyono. 2017. Metode Penelitian Bisnis Kuantitatif, Kualitatif, Kombinasi dan $R \& D$. Bandung: Alfabeta.

Suharyadi dan Purwanto, 2015. Statistika Untuk Ekonomi Dan Keuangan Modern Buku 2. Jakarta: Salemba Empat.

Sujarweni Wiratna V. 2016. Kupas Tuntas Penelitian Akuntansi dengan SPSS. Yogyakarta: Pustaka Baru Press.

Waluyo. 2016. Akuntansi Pajak Edisi 6. Jakarta : Salemba Empat.

\section{Referensi Jurnal:}

Anouar, D., \& Houria, Z. 2017. The Determinants of Tax Avoidance within Corporate Groups:Evidence from Moroccan Groups. International Journal of Economics, Finance and Management Sciences: Vol. 5, No.1 2017. Page: 57-65. ISSN : 2326-9561. doi: 10.11648/j.ijefm.20170501.15

Aprianto, M., \& Dwimulyani, S. 2019. Pengaruh Sales Growth dan Leverage Terhadap Tax Avoidance dengan Kepemilikan Institusional sebagai Variabel Moderasi: Jurnal Prosding Seminar Nasional Pakar ke 2 Tahun 2019. ISSN: 2615-2584
Dewinta, I. A., \& Setiawan, P. E. 2016. Pengaruh Ukuran Perusahaan, Umur Perusahaan, Profitabilitas, Leverage Dan Pertumbuhan Penjualan Terhadap Tax Avoidance. E-Jurnal Akuntansi Universitas Udayana : Vol. 14, 3 Maret 2016: 1584-1613 ISSN : 2302-8556

Dharma, I. M., \& Ardiana, P. A. 2016. Pengaruh Leverage, Intensitas Aset Tetap, Ukuran Perusahaan Dan Koneksi Politik Terhadap Tax Avoidance. EJurnal Akuntansi Universitas Udayana : Vol. 15, 1 April 2016 : 584-613. ISSN : 2302-8556

Dirvi Surya Abbas, Arry Eksandy. (2020). The Effect Of Effective Tax Rate, Tunneling Incentive, And Exchange Rate On Company Decisions To Transfer Pricing : Food And Consumption Sub-Sector Companies Listed On The Indonesia Evidence. Palarch's Journal Of Archaeology Of Egypt / Egyptology, 17(7), 14430-14442. Retrieved From

Https://Archives.Palarch.N1/Index.Php/Jae/Ar ticle/View/5486

Firmansyah, A., \& Muliana, R. 2018. The Effect of Tax Avoidance and Tax Risk on Corporate Risk. Jurnal Keuangan dan Perbankan University of Merdeka Malang : Vol. 22 No. 4 Juli 2018 : 643-656. ISSN : 2443-2687

Herawati, H dan D. Ekawati. 2016. Pengaruh Perencanaan Pajak Terhadap Nilai Perusahaan. Jurnal Riset Akuntansi dan Keuangan : Vol.4, No.1 2016. ISSN : 2338-1507

Handayani, Rini. 2018. Pengaruh Return on Assets (ROA), Leverage dan Ukuran Perusahaan Terhadap Tax Avoidance Pada Perusahaan Perbankan yang Listing di BEI Periode Tahun 2012-2015. Jurnal Akuntansi,Maranatha: Vol. 10, No.1, Mei 2018: 72-84. ISSN: 2085-8698

Hidayat, Wastam Wahyu. 2018. Pengaruh Profitabilitas, Leverage dan Pertumbuhan Penjualan Terhadap Penghindaran Pajak: Studi Kasus Perusahaan Manufaktur di Indonesia. E- 
Jurnal Riset Manajemen dan Bisnis Universitas Bhayangkara, Jakarta: Vol. 3, No. 1, Februari 2018 : 19- 26. ISSN : 2581-2165

Irianto, B. S., Sudibyo, Y., A \& Wafirli, A. 2017. The Influence of Profitability, Leverage, Firm Size and Capital Intensity Towards Tax Avoidance. International Journal of Accounting and Taxation Jendral Soedirman, University : Vol. 5, No. 2 December 2017 Page 33-41. ISSN : 2372-4978

Lestari, Nanik \& Wardhani, Ratna. 2015. The Effect of the Tax Planning to Firm Value with Moderating Board Diversity: International Journal of Economics and Financial Issues: Vol. 5, 2015. Page: 315-323. ISSN: 2146-4138

Kimsen, Kismanah, I., \& Masitoh, S. 2018. Profitability, Leverage, Size of Company Towards Tax Avoidance: Jurnal Ilmiah Akuntansi Fakultas Ekonomi, Muhammadiyah Tangerang: Vol. 4, No.1, Juni 2018: 29-36. ISSN: 2502-3020

Mahanani, A., Hendra,T.,K.,\& Nurlela, S. 2017. Pengaruh Karakteristik Perusahaan, Sales Growth dan CSR Terhadap Tax Avoidance: Jurnal Seminar Nasional IENACO-2017. ISSN: 23374349

Mappanyuki, R., \& Sari, M. 2017. The Effect of Sales Growth Ratio, Inventory Turn OverRatio, Growth Opportunity To Company's Profitability (Survey In Indonesia's Stocks Exchange). International Journal of Management and Applied Science Diponegoro, University : Vol. 3 No.3, March 2017. ISSN : 2394-7926

Okrayanti, T., Y., Utomo, S., W., \& Nuraina, E. 2017. Pengaruh Karakteristik Perusahaan Corporate Governance Terhadap Tax Avoidance (Studi Pada Perusahaan Manufaktur di BEI). E-Jurnal Forum Ilmiah Pendidikan Akuntansi Universitas PGRI Madiun: Vol. 5, No.1
Oktober 2017: Page 804- 817. ISSN : 2337-9723

Oktaviyani, R., \& Munandar, A. 2017. Effect of Solvency, Sales Growth, and Institutional Ownership on Tax Avoidance with Profitability as Moderating Variables in Indonesian Property and Real Estate Companies. Journal Binus Business Review : Vol. 8 No. 3, November 2017 : 183-188. ISSN : 2476-9053

Pattiasina,V., Tammuba, M., H., Numberi, A., Patiran, A., \& Temalagi, S. 2019. Capital Intensity and Tax Avoidance a case in Indonesia International Journal of Social Sciences and Humanities : Vol. 3, No.1, April 2019: Page 58-71. ISSN : 25507001

Permata, A., Nurlela, S., dan E. Wahyuningsih.2018. Pengaruh Size, Age, Profitability, Leverage, dan Sales Growth Terhadap Tax avoidance. Jurnal Akuntansi dan Pajak : Vol. 19, No.1 Maret 2018. ISSN : 2579-3055

Permatasari, A., N., Rahadian, D.,\& Yunita, I. 2017. Pengaruh CAR, LDR, BOPO, NPL dan Ukuran Perusahaan terhadap Profitabilitas. E-Proceeding of Management : Vol.4, No.2 Agustus 2017 I Page 1296. ISSN : 2355-9357

Pranata, D., \& Pujiati, D. 2015. The Effect of Liquidity, Profitability, Sales Growth, and Dividend Policy on Stock Prices After the Implementation IFRS. Jurnal The Indonesian Accounting Review Vol.5, No. 2, July 2015. Pages: 169- 178. DOI: $10.14414 /$ tiar.v5i2.559

Prastiwi, D., \& Ratnasari, R. 2019. The Influence of Thin Capitalization and the Executives Characteristics Toward Tax Avoidance by Manufactures Registered on Ise in 2011-2015: Jurnal Akuntansi: Vol. 10, No.2, April 2019: 119-134. ISSN: 2085-9643

Puspita, D., \& Febrianti, M.2017. FaktorFaktor Yang Memengaruhi Penghindaran Pajak Pada Perusahaan Manufaktur Di bUrsa Efek Indonesia. E-Jurnal Bisnis 
dan Akuntansi STIE Trisakti : Vol. 19, No. 1, Juni 2017: 38-46. ISSN: 14109875

Putri, T., R., F., \& Suryarini, T. 2017. Factors Affecting Tax Avoidance on Manufacturing Companies Listed on IDX. Accounting Analysis Journal : Vol. 6 No. 3 September 2017. ISSN : 2252-6765

Razali, M.W. M., Yi, P. X., Brahmana, R.K., \& Tak, A. H. 2019. Malaysian Listed Firm's Tax avoidance: Another Earnings Management Strategy?. International Journal of Academic Research in Business and Social Sciences : Vol. 9, No. 2, March 2019. Page: 643655. ISSN : 2222-6990

Turyatini. 2017. The Analysis of Tax Avoidance Determinant on The Property and Real Estate Companies. E-Jurnal Dinamika Akuntansi : Vol. 9 No. 2, September 2017: PP. 143-153. ISSN : 2502-6224

Satyadini, Agung Endika. 2018. Empirical Approach of Tax Avoidance Risk Assessment. Jurnal Kajian Ekonomi \& Keuangan: Vol. 2, No. 1, Mei 2018. DOI: 10.31685/kev.v2i1.344

Swingly, C., \& Sukartha, I. M. 2015. Pengaruh Karakter Eksekutif, Komite Audit,Ukuran Perusahaan, Leverage Dan Sales Growth Pada Tax Avoidance. E- Jurnal Akuntansi Universitas Udayana : 10.12015 : 47-62. ISSN : 2302- 8556

Yanti, L., D., \& Hartono, L. 2019. Effect of Leverage, Profitability and Company Size on Tax Aggressiveness. (Empirical Study: Subsector Manufacturing Companies Food, Beverage, Cosmetics and Houehold Purposes Manufacturing Listed on the Indonesia Stock Exchange foe 2014-2017). Ejournal KDI: Vol. 1, No. 1, February 2019. ISSN: 2656-0941 